\title{
Management Controlling of Progamme Desa Mandiri Cinta Petani in Timor Tengah Utara Regency
}

\author{
Sulistio Diliwanto Binsasi, Endang Larasati, Ida Hayu Dwimawanti \\ Magister Ilmu Administrasi Publik, Universitas Diponegoro Semarang, Indonesia \\ Email: sulistio.binsasi@yahoo.com
}

(Received: April 25-2019; revised: May 9 -2019; published: May 31-2019)

\begin{abstract}
Management controlling is a important role in the implementation of a program, because this function has a role to measure the suitability of activities with a predetermined plan. The purpose of this study was to analyze and describe the supervisory function in the management of the independent love village farmers program (Sari Tani) in Timor Tengah Utara Regency. The formulation of the problem in this study is how the supervision function of the farmer sari program in Timor Tengah Utara Regency. To answer these problems, the management is used which has relevance to the phenomenon of research. This research is a qualitative research with Milles and Huberman data analysis techniques. The results of the study showed that control in the program management of the independent love villages of farmers in Timor Tengah Utara Regency was not yet in line with the technical guidelines. As a result of the large amount of arrears on farmer sari refunds and the jamming of the farmers' funds, due to lack of awareness of beneficiaries who do not want to return Fund of sari tani programs (DST), Sari Tani Programe management unit (UPST) administrators do not comply with regulations relating to DST rolling procedures, and there is no direct action or direct affirmation to beneficiaries who have not repaid the refund of the farmer's juice.
\end{abstract}

Keywords: Controling Management; Sari Tani Program; Management

\section{INTRODUCTION}

Poverty is a classic problem faced by every country, one of which is Indonesia. Globally Poverty is usually defined as the inability of a person or family to fulfill their basic needs, as stated by Brevik et al. (2019) that they are said to be poor because of low income so they cannot meet basic needs such as clothing, food and shelter. Another thing stated by Hinsch \& Stepanians (2005) is that poverty is a condition in human life and also a phenomenon that is difficult to eliminate, even though various efforts have been made. Poverty that occurs in society is generally related to policy issues in certain groups. So, from the two opinions above, it can be formulated that poverty is the inability of people, families or communities to fulfill their daily basic needs, both material and non-material, and poverty is influenced by sociocultural life in a local wisdom area. Indonesia is a developing country that is still wrapped up in the problem of poverty, the challenge facing Indonesia today is the still high number of poor people, which can be seen in the condition of September 2017 which reached 26.58 million people (10.12 percent) and the slow decline in poverty rates the average year from September 2013 to September 2017 is $0.2 \%$ (Bozeman \& Youtie, 2017).

The province of East Nusa Tenggara (NTT) is one of the poorest regions in Indonesia, with a poor population reaching 1,134.74 million or 21.38\% (Badan Pusat Statistik, 2017). The condition of the number of poor people in Provisinsi in NTT is more prevalent in rural areas, 
20 | Jurnal Ilmiah Ilmu Administrasi Publik: Jurnal Pemikiran dan Penelitian Administrasi Publik Volume 9 Number 1, January - Juny 2019. Page 19-28

namely in September 2017 it reached $1,015.72$ million while the number of poor people in urban areas was 119.04 thousand. One of the districts in the NTT Province which is classified as poor, namely North Central Timor Regency. This as in Badan Pusat Statistik (2018) explained that the poverty rate of Timor Tengah Utara district from 2015 to 2017 decreased the percentage of poverty. In 2015 the percentage of poverty of $24.07 \%$ fell to $23.52 \%$ in 2016 or by $1.13 \%$ and from 2016 the poverty rate of $23.52 \%$ fell to $22.31 \%$ in 2017 or $0.55 \%$. Although there is a decrease in the percentage of poverty in TTU, but the percentage of poverty in TTU district is still higher than the percentage of poverty in NTT Province, which is $21.35 \%$.

The poverty picture of North Central Timor Regency can be seen from the number of poor people, and per capita income shown in figure 1 .

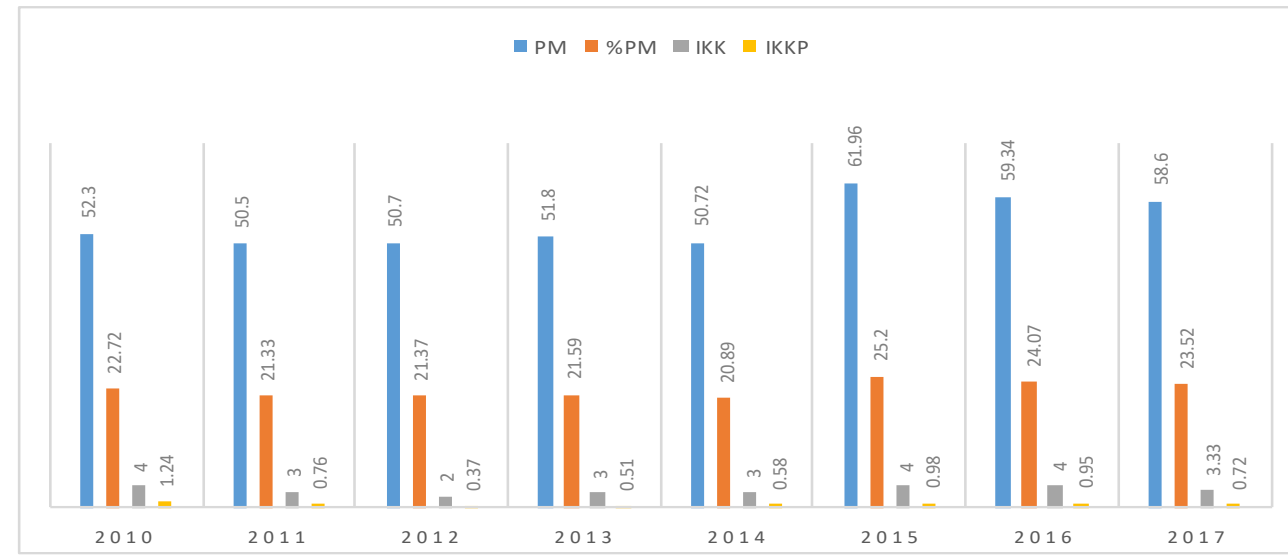

Source: Poverty Data and Information BPS RI 2017

Figure 1

Poverty Line, Percentage of Poor Population and Poor Population (Thousands) in North Timor Tengah District, 2010-2017

The data shows that the poverty rate has decreased in 2010-2011 but in 2012-2017 the poverty rate looks fluctuating, where in 2013 it increased from $50.70 \%$ to $51.80 \%$ then in 2015 it increased in 2014 which was $50.72 \%$ to $61.96 \%$, in 2016 decreased from $61.96 \%$ to $59.34 \%$, and in 2017 decreased to $58.6 \%$. And from per capita income, the depth index of the poverty gap index and the poverty severity index poverty severity index have increased. This shows that the poverty rate in North Central Timor Regency is volatile.

TTU District Government Making policies for the Cinta Petani (Sari Tani) Independent Village Program as a flagship program initiated by Raymundus Sau Fernandes, S.Pt in 2010 to address the problem of poverty in North Timor Tengah District. This program is designed with a pattern of empowering rural communities through the development of various superior potentials available, so as to increase community independence and increase the incomes of the poor. The problem of poverty is still the main agenda in the Regional Medium Term 
Development Plan (RPJMD) of Timor Tengah Utara Regency 2016-2021, which requires rapid and appropriate handling. So that the strategic farming program is still an important part that continues to be carried out continuously.

The aim of the Independent Cinta Petani (SariTani) Village Program is to provide employment opportunities that focus on developing productive businesses in agriculture and animal husbandry in order to improve the welfare of the poor in the village. Specifically, the general objectives of this program can be described as follows: 1) Reducing poverty in the village, 2) Increasing business opportunities for the poor in the village, 3) developing superior potential in agriculture and livestock in TTU district, 4) Increase the fiscal capacity of the village.

The target of the Sari Tani Program is to describe the performance targets that are measurably specific, easily achieved, rational and directed so that the desired goals are achieved. The following are the objectives of the Sari Tani Program, namely:

1. Increased village community income from Rp. 5,567,626 in 2016 to Rp. 8,067,626 in 2021.

2. Reducing the percentage of rural poor families from $21.59 \%$ of poor families in 2016 to $18.59 \%$ in 2021.

3. The creation of 1000 productive business units among rural communities in 2021.

4. Establishment of 183 healthy Village financial institutions in 2021.

5. Realization of 6 types of superior products in the district in 2021.

6. Increase the average village original income (PADes) from Rp. 7,500,000 in 2016 to 11,500,000 in 2021 (Juknis Sari Tani 2016).

Cinta Petani (Sari Tani) Mandiri Village Program North Central Timor Regency focuses on developing productive economic activities of rural communities by providing perpetual revolving capital assistance which is the TTU District Government financial assistance to the Village Government from 300,000,000 million APBD to each village with details of $250,000,000$ million for the development of district superior products, the operation of the $40,000,000$ million farmers 'sari fund management unit (UPST), and 10,000,000 for training the farmers' sari fund management unit (UPST). The superior types of products developed in the regency are in agriculture: corn, peanuts, garlic, salt while in the field of livestock: cattle, pigs based on the potential in the village. With the total village receiving farm sari funds as many as 161 villages through 3 stages of realization, namely:

1. In 2012 the number of villages that received Sari Tani funds was 24 villages with funds of Rp. 7,200,000,000,

2. In 2013 the number of villages that received Sari Tani funds was 36 villages with funds of Rp. 10.8 million,

3. In 2014 the number of villages that received Sari Tani funds was 101 Villages with funds of Rp. 30,300,000,000. (Juknis Sari Tani 2016)

The farm sari program has been running since 2012 until now, but this program has not yet reached its target to reduce the presentation of poverty in TTU District. Data from TTU Regency BPS (2017) shows that the percentage of TTU poverty still reaches $22.31 \%$. In addition, in the implementation of the sari sari program, there were also various obstacles in his management, one of which was the supervisory function. Supervision is a management function 


\section{Jurnal Ilmiah Ilmu Administrasi Publik: Jurnal Pemikiran dan Penelitian Administrasi Publik Volume 9 Number 1, January - Juny 2019. Page 19-28}

that helps provide an assessment of the extent to which planning, organizing, drafting personnel, and directing are carried out effectively. In the management of the farm sari program it is suspected that there is a problem with the supervisory function of this matter because there are problems arising in the refund of the farmers' extraction and the default of revolving funds, as specified in table 1 below:

\section{Table 1}

The Revolving of Cinta Petani (Sari Tani) Mandiri Village Program in Timor Tengah Utara Regency in August 2018

\begin{tabular}{rrrrrrrr}
\hline $\begin{array}{c}\text { No } \\
\text { year }\end{array}$ & $\begin{array}{c}\text { Fiscal } \\
\text { of } \\
\text { villages }\end{array}$ & $\begin{array}{c}\text { Total of } \\
\text { groups }\end{array}$ & $\begin{array}{c}\text { Number of } \\
\text { members }\end{array}$ & Loan principal & Total Returns & Total arrears \\
\hline 1 & 2012 & 24 & 195 & 2943 & $6,128,519,615.00$ & $4,204.033 .268 .02$ & 1.924 .486 .347 \\
2 & 2013 & 36 & 209 & 2605 & $7,781,913,500.00$ & 2.497 .452 .510 .00 & 5.642 .010 .015 .00 \\
3 & 2014 & 101 & 464 & 5993 & $20,479,965,000.00$ & 2.628 .616 .300 .00 & 16.642 .525 .100 .00 \\
\hline & Total & 161 & 868 & 11541 & 34.390 .398 .115 .00 & 5.126 .068 .810 .00 & 22.284 .535 .115 .00
\end{tabular}

Source: Community Empowerment and Village Governance Agency (CEVGA/BPMPD) 2018

Based on the data above, it is known that arrears problems always occur every period of revolving of farmers' sari funds, even if in total the total arrears of farm sari funds reaches $22,284,535,115.00$ or $(64.8 \%)$ of total loans. The existence of these arrears has resulted in a breakdown in the revolving of the farmers 'sari funds for other poor people, which has a subsequent impact on the achievement of the objectives of other farmers' extraction programs. Therefore, it is important to conduct a study of the supervisory function in the management of the farm extraction program, so that the formulation of the problem in this study is how the monitoring function of the farmer sari program is in North Timor Tengah District.

\section{METHOD}

The method used in this study is descriptive qualitative with an explorative approach. As stated by Arikunto (2006) that, "Descriptive research is research that is intended to collect information about the status of existing symptoms, namely the conditions according to what they are at the time the research was conducted". More thant Creswell \& Creswell (2017) say that "qualitative research is a research approach to uncover certain social conditions by describing reality correctly, formed by words based on relevant data collection techniques obtained from natural situations. Explorative approach is that researchers want to explore natural phenomena that have not been revealed, describe an actual situation and interpret it based on methods and techniques of data analysis. The focus of this research was to analyze the function of supervision in the management of the farm sari program in North Timor Tengah 
District. The informant selection technique in this study used tekik purposive, and also used snowball techniques to obtain complete and accurate information. The data analysis technique used in this study is to use qualitative data analysis techniques following the concept (Miles, Huberman, \& Saldaña, 2014), namely by "data reduction, data presentation, data condensation, and conclusions.

\section{RESULT AND DISCUSSION}

Public management is basically government management in regulating, serving public needs. This is as stated by Overman (1996) that public management is not "scientific management", although it is strongly influenced by "scientific management". Public management is not "policy analysis" nor public administration, reflects the pressures between the orientation of the "rational instrumental" on the one hand, and the political orientation of the other party's policies. Public management is an interdisciplinary study of the combination of planning, organizing, and controlling existing management functions with management of human resources, physical, financial, and political finance.

Public management can also be interpreted as a complex performance from the role of the government and all its employees to serve the community as well as possible so that the public or the community can meet their needs with the performance culture and regulation of the public organization. More advanced Shafritz \& Hyde (2016) state that in public administration there are two important fields, namely public policy and public management, both fields can be analogous to the work system of the heart with circulation of blood in the human body. Then it can be said that public management is a process of carrying out government policies in accordance with the regulations stipulated.

George R Terry \& Rue, 1987 and George Robert Terry \& Franklin, (1968), in his book Principles of Management, describes 4 main functions in management, namely planning, organizing, actuating, and controling. These concepts are explained in the table 2 below:

Table 2.

Concept of Function Management George R. Terry (George Robert Terry \& Franklin, 1968)

\begin{tabular}{lll}
\multicolumn{1}{c}{ Question } & $\begin{array}{l}\text { Fundamental Function of } \\
\text { Management Used }\end{array}$ & \multicolumn{1}{c}{ Result } \\
\hline $\begin{array}{l}\text { What is the need? What courses of action } \\
\text { should be adopted and how and when } \\
\text { should they be followed? }\end{array}$ & Planning & $\begin{array}{l}\text { Objectives, policies, } \\
\text { procedures, and methods }\end{array}$ \\
\hline $\begin{array}{l}\text { Where should actions take place and who } \\
\text { should do what work? }\end{array}$ & Organizing & $\begin{array}{l}\text { Work division, work } \\
\text { assignment, and authority } \\
\text { utilization }\end{array}$ \\
\hline $\begin{array}{l}\text { Why and how should group members } \\
\text { perform their respective tasks? }\end{array}$ & Actuating & $\begin{array}{l}\text { Leadership, communication, } \\
\text { development, and incentives }\end{array}$ \\
\hline $\begin{array}{l}\text { Are the actions being performed when, } \\
\text { where, and how - in accordance with } \\
\text { plans? }\end{array}$ & Controlling & $\begin{array}{l}\text { Reports, comparisons, costs, } \\
\text { and budgets }\end{array}$ \\
\hline
\end{tabular}

Source: George Robert Terry \& Franklin, 1968 


\section{4 | Jurnal Ilmiah Ilmu Administrasi Publik: Jurnal Pemikiran dan Penelitian Administrasi Publik Volume 9 Number 1, January - Juny 2019. Page 19-28}

From the picture above, it can be explained that there are 4 main functions of management, namely Planning related to determining the goals and actions that must be carried out by an organization. Organizing is related to the division of tasks, work assignments, and utilization of resources. Actuating which includes aspects of leadership, communication, development of organizational members, and incentives in organizations to achieve goals. Controling is related to reports, comparison of costs with budget, and measuring the suitability of activities with plans that have been set.

Alexander, Alterman, \& Law-Yone (1983) reveals supervision as an activity to measure implementation with predetermined plans relating to criteria, standards, and norms. That supervision is a process to ensure that organizational and management goals are achieved (Akib \& Saleh, 2015; M. S. Saggaf et al., 2018; S. Saggaf, Salam, Kahar, \& Akib, 2014). This is related to ways to make activities as planned.

The purpose of supervision is:

1. Determine and eliminate the causes that cause difficulties before the difficulties occur.

2. Conduct prevention and repair of errors that occur.

3. Getting efficiency and effectiveness (Sutarno NS 2004: 128).

Based on the description above it can be concluded that supervision is an evaluation and monitoring activity during the course of activities to carry out repairs and becomes a reference material for planning the next program objectives to be better. The function of management supervision is closely related to other management functions, this can be seen in Figure 2.

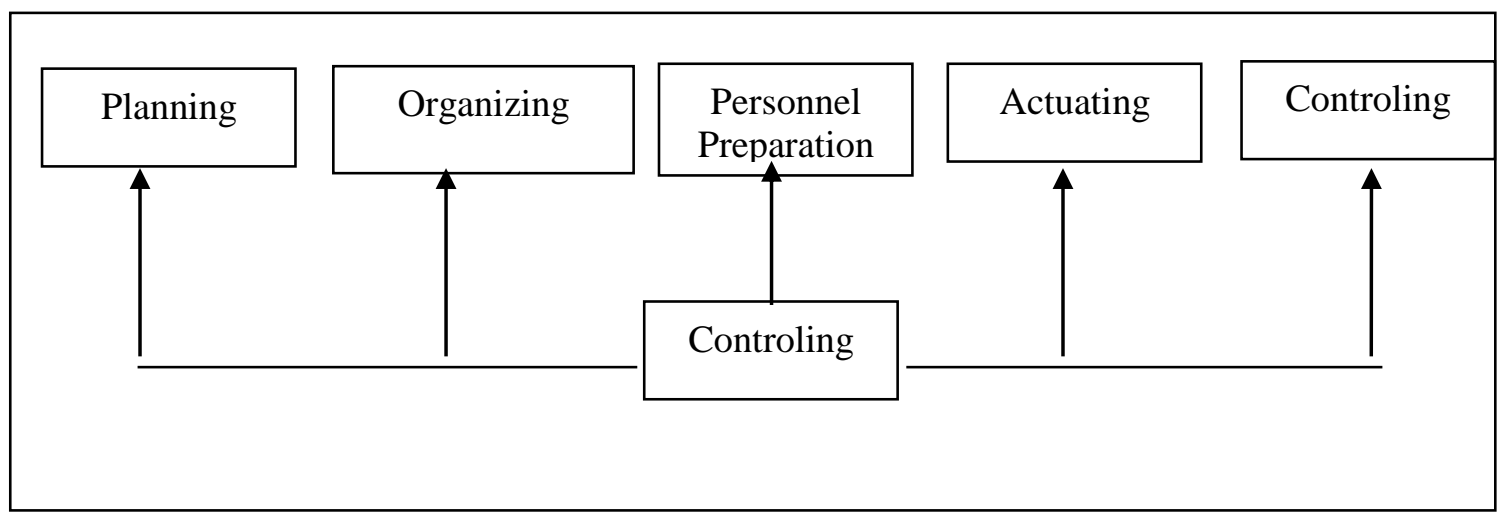

Source : Handoko (2009:360)

Figure 2

Supervision Relations with Other Management Functions

Based on the picture above it can be explained that the function of supervisory management helps provide an assessment of the extent to which planning, organizing, composing personnel, and directing are carried out effectively. In the science of supervision management is the last step to carry out monitoring, evaluation of all organizational activities 
whether it is in accordance with the plan set. Oversight in the management of the farm extraction program can be used as a tool to see whether the performance of the farmer management program is in accordance with the technical guidelines set.

The following is a sub-phenomenon to explain the supervision in a farmers' independent love village program in North Central Timor Regency.

\section{Actions Conducted to Improve the Revolving of Dana Sari Tani, in the North Central Timor Regency}

Supervision in the Management of the Sari Tani Program needs to be carried out by the parties concerned as stipulated in the technical guidelines including the TTU Regency DPMD, the District to the village level. The control carried out by the DPMD of North Central Timor Regency is by coordinating and cooperating with the sub-districts, villages and PKM.

Activities that have been established in the management process of the farm extraction program management will not bring effective results if not accompanied by control measures by program implementers both in the district to the village level. The effort of the Village and Community Empowerment Service Office of Timor Tengah Utara Regency as the responsible person for the district level program always coordinates with program implementers at the subdistrict level to the village level. This is to measure the success rate of the farm extraction program and can record problems in the return and revolving of the program.

The results of research in the field relating to actions to increase the revolving of the sari sari farm in TTU District, it was known that coordination had been carried out both from the DPMD to the village level. At the district level through DPMD always supervises the PKM performance with a coordination meeting (Rakor), at the sub-district level it is always confirmed to the village heads about the revolving of Dana Sari Tani (DST) at the awareness ceremony every 17th of every month, but at the sub-district and village level there are no plans work in increasing DST revolutions. Confirmation efforts at the awareness ceremony were not enough because many village heads did not follow up on the affirmation, while the village head did not coordinate with the Program Assistant (PKM) and the Sari Tani Program Management Unit (UPST) for DST billing and revolving, as well as at the sub-district level. even at the village level there has been no direct action or treatment for beneficiaries who have not paid back the DST.

\section{Conformity with the Technical Guidelines That Have Been Determined in Returning and Revolving Dana Sari Tani in Timor Tengah Utara Regency}

\section{Sari Tani Refunds}

The DST farm extraction fund is an endowment that is a revolving capital for microeconomic development in the village. As such, the funds were not returned to the cash of the North Central Timor Regency. But it was rolled out according to the mechanism. For the continuity of the DST revolutions to other farmer groups / fishermen, then the DST must be returned, that is, from members to UPST administrators, who then deposited a special account of the Village. 
26 | Jurnal Ilmiah Ilmu Administrasi Publik: Jurnal Pemikiran dan Penelitian Administrasi Publik Volume 9 Number 1, January - Juny 2019. Page 19-28

The period of DST return by members of farmer groups / fishermen is carried out after the commodities that have been cultivated are harvested / sold under the following conditions:

1. DST returns are carried out simultaneously, namely after harvesting commodities and / or maximum within 12 months;

2. The amount returned is principal plus interest;

3. The amount of interest is determined by the UPST manager based on the results of the village meeting, but not less than $6 \%$ and not more than $10 \%$. In other words, the DST interest expense ranges from $6 \%-10 \%$.

4. Returns on DST debt can be in the form of cash and / or commodities. If the return is in the form of commodity, then the volume of the commodity must be equal to the value of the debt plus interest based on the market price of the commodity that is being applied in the local market.

The results of research on the management of the farmers' extraction program in Timor Tengah Utara Regency relating to farm extraction refunds found that the return procedure for Dana Sari Tani has been set for a repayment period of 12 months or one year as stipulated, but has not yet been implemented from 2012 to 2018. In accordance with existing farmer manuals, there are still many arrears in Dana Sari peasant returns in TTU District due to lack of awareness of beneficiaries where beneficiaries consider this program Free or grants to the people this understanding is the reason for them to return Dana Sari Tani to be rolled out. The declining market prices of beneficiary farmers sometimes collide with falling prices for postharvest commodities such as peanut prices, and corn prices so that the proceeds do not meet the needs of their beneficiaries, especially for returns, lower prices of peanuts and corn because almost all farmers grow these commodities especially the beneficiaries of farmers' extraction, the weakness of the government in designing programs does not create a market. and the demands of the recipient's economic needs.

\section{Revolving of Dana Sari Tani}

In the technical guide for the independent village program, the farmers also regulate the revolving pattern of the sari sari farm in Timor Tengah Utara Regency with several provisions, namely:

1. UPST managers are required to redistribute DST to new groups that have been nurtured / carried out or to old groups that have achievements or if there are still members who have not received DST capital but do not have loans to other programs.

2. Before compiling the revolving proposal, UPST must report the results of group verification to the Village Head and Sub-District Head.

3. The DST manager is not permitted to store the DST resulting from the claims in the UPST account in the amount exceeding Rp.2,500,000;

4. In accordance with the provisions of letter b), if the UPST account balance has reached a minimum of Rp.2,500,000, the UPST management must redistribute the DST to another group; 
5. The balance of the UPST account must be announced at the announcement stage of the UPST secretariat to ensure the transparency of the management of the billed DST results.

6. Terms of groups and members of the DST recipient group redistribution and distribution procedures are the same as the terms and procedures of the initial DST recipient with priority are new groups that have been fostered or confirmed or old groups that have good performance

7. Mandatory revolving requirements for members who have received Sari Tani Fund are ownership of 1 (one) cow or pig purchased from the proceeds of the sale of cattle or pigs previously.

Sari Tani Fund wrestling is an important thing in the management of the farm sari program where with rolling it will create even distribution of beneficiaries in the village and achieve the set targets, but the problem that occurs is not only in returning DST but the issue of DST revolutions in the village.

The results of interviews with informants in this study found the revolving of Sari Tani Fund not in accordance with the technical guidelines, because there are still many DST returns, the returns in DST returns occur in all villages that received this program in TTU District, this complicates the revolving process for other groups in the village that is. And UPST management's disobedience regarding the procedures for rolling out DST, for example DST returns have not reached $100 \%$ but UPST and PKM do not want to pass DST to other groups. This is because there will be problems if in the revolt again and many group members do not get the benefits of the program, and will hinder the return process for new beneficiaries because the old beneficiaries see examples of previous beneficiaries who have not paid it off.

\section{CONCLUSION}

Controlling the farm extraction program in Timor Tengah Utara Regency is not yet in line with the technical guidelines. This is indicated by the large arrears of farmer sari refunds and the jamming of the farmers' sari funds, which due to lack of awareness of beneficiaries who do not want to return DST, UPST administrators do not comply with regulations relating to the DST revolving procedure, and there is no direct action or affirmation directly to the beneficiaries who have not paid off the refund of the farmer's juice. Based on the description of the conclusions above, the advice given is related to the supervisory function in the management of the Sari Tani program in North Central Timor Regency, namely: 1). The Department of Community and Village Empowerment of North Central Timor District needs to hold regular coordination meetings with Kecamatan, village, PKM, and UPST executive teams, 2). Peasant companion staff (PKM) need to be equipped with knowledge, skills and dedication so that they are professional in carrying out their duties in the village. 3). Need to improve evaluation and monitoring by sub-districts and villages of PKM, UPST, and beneficiaries. 4). The Timor Tengah Utara District Government needs to give an award as a form of village motivation, a companion (PKM) who returns and revolves $100 \%$ of the farmers' juice according to the specified time period. 
28 | Jurnal Ilmiah Ilmu Administrasi Publik: Jurnal Pemikiran dan Penelitian Administrasi Publik Volume 9 Number 1, January - Juny 2019. Page 19-28

\section{REFERENCES}

Akib, H., \& Saleh, S. (2015). Pengaruh Kepala Sekolah Sebagai Supervisor Terhadap Kinerja Guru Di Smk Negeri 7 Makassar. Jurnal Office, 1(2), 141-147.

Alexander, E. R., Alterman, R., \& Law-Yone, H. (1983). Evaluating plan implementation: The national statutory planning system in Israel. Progress in Planning, 20, 101-172. https://doi.org/https://doi.org/10.1016/0305-9006(83)90002-8

Arikunto, S. (2006). Metode Penelitian Kualitatif. Jakarta: Bumi Aksara.

Badan Pusat Statistik. (2017). Badan Pusat Statistik. Badan Pusat Statistik.

Badan Pusat Statistik. (2018). Presentase Penduduk Miskin Menurut Kabupaten/Kota di Provinsi Nusa Tenggara Timur.

Bozeman, B., \& Youtie, J. (2017). Socio-economic impacts and public value of governmentfunded research: lessons from four US National Science Foundation initiatives. Research Policy, 46(8), 1387-1398.

Brevik, E. C., Pereg, L., Pereira, P., Steffan, J. J., Burgess, L. C., \& Gedeon, C. I. (2019). Shelter, clothing, and fuel: Often overlooked links between soils, ecosystem services, and human health. Science of The Total Environment, 651, 134-142. https://doi.org/https://doi.org/10.1016/j.scitotenv.2018.09.158

Creswell, J. W., \& Creswell, J. D. (2017). Research design: Qualitative, quantitative, and mixed methods approaches. Sage publications.

Hinsch, W., \& Stepanians, M. (2005). Severe Poverty as a Human Rights Violation-weak and strong. In Real World Justice (pp. 295-315). Springer.

Miles, M. B., Huberman, A. M., \& Saldaña, J. (2014). Qualitative data analysis: A methods sourcebook. 3rd. Thousand Oaks, CA: Sage.

Overman, E. S. (1996). The new science of management: Chaos and quantum theory and method. Journal of Public Administration Research and Theory, 6(1), 75-89.

Saggaf, M. S., Aras, M., Akib, H., Salam, R., Baharuddin, A., \& Kasmita, M. (2018). The Quality Analysis of Academic Services Based on Importance Performance Analysis (IPA).

Saggaf, S., Salam, R., Kahar, F., \& Akib, H. (2014). Pelayanan Fungsi Administrasi Perkantoran Modern. Jurnal Ad'ministrare, 1(1), 20-27.

Shafritz, J. M., \& Hyde, A. C. (2016). Classics of public administration. Nelson Education.

Terry, George R, \& Rue, L. W. (1987). Principios de administración. El Ateneo,.

Terry, George Robert, \& Franklin, S. G. (1968). Principles of management. RD Irwin. 